\title{
EMBARCANDO NO MUNDO DA LEITURA E DAS BRINCADEIRAS
}

\author{
Bianca Marcelino $^{1}$
}

Atuamos em uma escola estadual da rede pública de Florianópolis/SC por meio do Programa Institucional de Bolsa de Iniciação à Docência (PIBID-PEDAGOGIA) da Universidade Federal de Santa Catarina (UFSC), com crianças dos anos iniciais do ensino fundamental, filhas de trabalhadores que vivem em comunidades com baixo poder aquisitivo.

O objetivo desse trabalho é apresentar reflexões sobre as atividades pedagógicas que realizamos com e para as crianças em dois momentos e espaços no ano de 2015. O primeiro ocorre em uma sala destinada ao atendimento de crianças com necessidades específicas de aprendizagem de leitura e escrita, denominada de Sala de Apoio e a segunda atividade foi realizada no horário do recreio escolar. Nossas ações nesses momentos foram pensadas e planejadas em conjunto com a coordenadora do projeto do PIBID PEDAGOGIA e com as professoras participantes deste programa na escola.

$\mathrm{Na}$ sala de Apoio Pedagógico tínhamos como intuito ampliar o repertório cultural literário das crianças, contribuindo pedagogicamente para a superação das dificuldades iniciais encontradas nos processos de alfabetização e letramento, bem como criar situações de ensino que respeitem a criança como ser humano em formação. Planejamos um espaço de leitura para as crianças, com as crianças e das crianças. Essa sala tornou-se um espaço agradável para que elas, em conjunto conosco, participassem de sua organização e pudessem sentir-se pertencentes do mesmo. GOULART (2006) nos diz que, o modo como organizamos o trabalho pedagógico está ligado ao sentido que atribuímos à escola e à sua função social, aos modos como entendemos a criança; aos sentidos que damos à infância e à adolescência e aos processos de ensino-aprendizagem. Buscamos realizar atividades que tivesse algum sentido com o cotidiano das crianças. Nossas atividades eram realizadas com as crianças das turmas de terceiro, quarto e quinto ano dos anos iniciais do ensino fundamental, realizávamos as atividades de leitura e escrita durante 45 minutos e duas vezes por semana com cada turma, as crianças eram sempre acompanhadas por nós bolsistas, por uma professora de turma e por nossa coordenadora. O planejamento semanal das atividades era em conjunto com todas as professoras e bolsistas, o planejamento era a partir do interesse da criança e necessidade específica de cada criança.

No que se refere à atuação no horário do recreio escolar, inicialmente propusemos diversas brincadeiras, tais como corda, pata cega, elástico, jogo da velha, bolinha de gude e também algumas brincadeiras que possuem cantigas, pois de acordo com SOUZA,

As brincadeiras acompanhadas de cantigas têm uma função complementar de desenvolver a rima, a sintaxe e, também, de cadenciar o movimento segundo ritmos estabelecidos e melodias. Nós sabemos hoje que a música atua diretamente no cérebro, desenvolvendo áreas para ritmo e melodia, áreas essas que são funcionais e necessárias para a aprendizagem da leitura e da escrita. (SOUZA,2007, p. 5)

Escolhemos essas brincadeiras, pois envolvem a participação de todas as crianças do primeiro ao quinto ano. Tínhamos como finalidade ampliar o repertório cultural, promovendo situações de ensino e de aprendizagem que possibilitem imaginar, criar noções relacionadas ao espaço, tempo, cooperação, conhecimentos em geral, dentre outros aspectos. Tais atividades possibilitaram que as crianças criassem relações de respeito e solidariedade um com o outro.

\footnotetext{
${ }^{1}$ Universidade Federal de Santa Catarina (UFSC).
} 
Pois, de acordo com SOUZA (2007), o brincar é o direito da infância. Essa é a primeira razão para que se defenda, em todas as instâncias da sociedade, que a criança tenha tempo, espaço e liberdade para brincar.

Percebemos que, a partir da realização das brincadeiras no recreio, o número de incidentes envolvendo as crianças, diminuiu consideravelmente. A partir das relações construídas com as crianças, conseguimos observar o quanto elas se sentiam acolhidas e mobilizadas, assim como nós estudantes bolsistas. Por meio dos encontros semanais de avaliação, planejamento das atividades e da atuação juntos às crianças e professoras, as brincadeiras e demais atividades de leitura organizadas intencionalmente geraram a apropriação de novos repertórios culturais e promovendo o desenvolvimento humano das crianças. A partir do que diz Charlot, conseguimos perceber que só aprendemos se houver consentimento, pois de acordo com o autor,

Ninguém poderá me educar-me se eu não consentir, de alguma maneira, se eu não colaborar; uma educação é impossível, se o sujeito a ser educado não investe pessoalmente no processo que o educa. Inversamente, porém, eu só posso educar-me numa troca com os outros e com o mundo; a educação é impossível, se a criança não encontra no mundo o que lhe permite constituirse. Toda educação supõe do desejo como força propulsionadora que alimenta o processo. Mas só há força de propulsão porque há força de atração: o desejo "de"; a criança só pode constituir-se porque o outro e o mundo são humanos e são desejáveis.(CHARLOT, 2000 p. 54)

Desse modo, ocorreu uma rica possibilidade de aprendizagem, que foi compartilhada por todos os envolvidos no programa. Tais encontros unem universidade pública e escola de educação básica na formação de professores com o objetivo de superar a dicotomia entre teoria e prática.

\section{Contribuições do Programa Institucional de Bolsa de Iniciação à Docência - PIBID - Pedagogia}

Professoras, diretora e coordenadoras abriram as portas da escola para que nós estudantes de Pedagogia da Universidade Federal de Santa Catarina pudéssemos aprender a ensinar e sermos professoras, apoiadas pelo Programa Institucional de Bolsa de Iniciação à Docência (PIBID- PEDAGOGIA).

Coletivamente, sujeitos da escola de educação básica e da universidade, aprenderam e ensinaram a ler, escrever, ouvir, falar, cantar e brincar. Além dessas aprendizagens, aprendemos algo muito importante, que é o respeito ao próximo e compreender que todos os sujeitos possuem direitos e esses devem ser respeitados, respeitar contribui para a formação do ser humano e se configuram como conteúdo de aprendizagem de professores, estudantes, adultos e crianças. Nós como estudantes universitárias percebemos que a escola pode ser vista de outras formas, pois é o melhor espaço para apropriação do conhecimento, das qualidades humanas, bem como de defesa e exercício dos direitos da criança. É por meio deste espaço que conseguimos unir a teoria e a prática, dando sentido a elas. No chão da escola percebemos que a história faz a particularidade dos sujeitos, que são capazes de atribuir sentidos ao que realizam e, se mobilizados por desejos, aprendem a serem crianças, estudantes e professores. Essa experiência de formação nos permitiu estabelecer relações entre teoria e a prática exercida na escola, o que torna a parte teórica mais fácil de ser compreendida. A atuação no PIBID nos possibilita ver o quão complexo é o cotidiano das professoras. 
O PIBID é uma oportunidade importante para nós estudantes dos cursos de licenciatura, pois é por meio dele que podemos entrar na escola e aprender a sermos professoras com a ajuda dos professores e das professoras junto com as crianças. Entrei para o programa no ano de 2012 no segundo ano de graduação, sempre digo que se pudesse escolher uma brincadeira para descrever a minha trajetória neste programa eu escolheria a Amarelinha, é uma brincadeira onde vamos fase por fase até chegar ao "FIM", mas durante o caminho vamos aprendendo como jogar a pedra, em qual casa jogar e ao mesmo tempo é necessário que tenhamos equilíbrio para não cair, é preciso ter persistência para chegar ao fim. Durante a minha trajetória fui de fase em fase compreendendo um pouco do que é ser professor, de como é importante darmos um passo de cada vez e não perder o equilíbrio nessa caminhada que é cheia de desafios e obstáculos. Essa amarelinha chamada PIBID me fez crescer, amadurecer e aprender. Esse jogo apareceu para mim como um momento de vivenciar e experimentar a carreira que eu tinha escolhido, essa oportunidade apareceu em um momento de dúvidas e incertezas.

Sou muito grata a todas as pessoas envolvidas na minha caminhada e ao PIBID, pois foi por meio deste que tive a oportunidade de conhecer todas as pessoas que contribuíram para a minha formação pessoal e profissional, foi por meio deste que conheci professoras e professores e muitas crianças que me acolheram e me deram oportunidade nesse processo de formação. Muito obrigada pelas dicas de como melhorar ou mudar, agradeço as crianças por me darem a oportunidade de aprender com elas de como ser professora e me cobrarem diariamente ser uma professora e pessoa melhor, e as professoras e professores que me acompanharam dentro e fora de sala, cada uma com algo para me ensinar.

\section{Referências}

CHARLOT, B. O "Filho do Homem": obrigado a aprender para ser (uma perspectiva antropológica). In: Artmed Editora, 2000. p. 51-58.

GOULART, C. A organização do trabalho pedagógico: alfabetização e letramento como eixos orientadores. In: BRASIL. MINISTÉRIO DA EDUCAÇÃO. Ensino Fundamental de nove anos. Disponível em: 〈http://portal.mec.gov.br/seb/arquivos/pdf/Ensfund/ensifund9anobasefinal.pdf>. 2006. p. 85-98.

LIMA, Elvira Souza. Brincar para quê. São Paulo: Inter Alia, 2007.

\section{Sobre a autora}

Bianca Marcelino é licenciada em Pedagogia pela Universidade Federal de Santa Catarina (UFSC). E-mail: biancamarcelin@gmail.com. 